\title{
Research Article \\ Effect of Keratin Structures from Chicken Feathers on Expansive Soil Remediation
}

\author{
Elda Montes-Zarazúa, ${ }^{1}$ Arturo Colín-Cruz, ${ }^{1}$ María de la Luz Pérez-Rea, ${ }^{2}$ Miguel de Icaza, ${ }^{3}$ \\ Carlos Velasco-Santos, ${ }^{3,4}$ and Ana Laura Martínez-Hernández ${ }^{3,4}$ \\ ${ }^{1}$ Posgrado en Ciencias Ambientales, Facultad de Química, Universidad Autónoma del Estado de México, \\ Paseo Colón Esquina Paseo Tollocan, 50120 Toluca, MEX, Mexico \\ ${ }^{2}$ Facultad de Ingeniería, Universidad Autónoma de Querétaro, Centro Universitario, Cerro de las Campanas, 76160 Querétaro, \\ QRO, Mexico \\ ${ }^{3}$ Centro de Física Aplicada y Tecnología Avanzada, Universidad Nacional Autónoma de México, Apartado Postal 1-1010, \\ 76000 Querétaro, QRO, Mexico \\ ${ }^{4}$ División de Estudios de Posgrado e Investigación, Instituto Tecnológico de Querétaro, \\ Avenida Tecnológico s/n Esquina Gral. Mariano Escobedo, Colonia Centro Histórico, 76000 Querétaro, QRO, Mexico
}

Correspondence should be addressed to Ana Laura Martínez-Hernández; almh72@gmail.com

Received 20 May 2015; Accepted 5 August 2015

Academic Editor: Michele Iafisco

Copyright ( 92015 Elda Montes-Zarazúa et al. This is an open access article distributed under the Creative Commons Attribution License, which permits unrestricted use, distribution, and reproduction in any medium, provided the original work is properly cited.

\begin{abstract}
Chicken feathers are composed mainly of avian keratin, a fibrillar protein with a complex structure, and important properties such as durability, hydrophobicity, being chemically unreactive, and depending on the specific function can change its morphological and inner structure. This study takes advantage of these features and for the first time the use of keratin from chicken feathers to modify characteristics on expansive soils is reported. Swelling characteristics of remolded expansive soil specimens were studied through varying the percentage of keratin fiber content using $0.25,0.50,1.00$ and $3.00 \mathrm{wt} \%$. One-dimensional swell-consolidation tests were conducted on oedometric specimens, specific surface area was determined using methylene blue, and degree of saturation was also analyzed. Finally random distribution and interaction between keratin structures and soil were studied by scanning electron microscopy. The results show that randomly distributed fibers are useful in restraining the swelling tendency of expansive soils. The maximum reduction of pressure (43.99\%) due to swelling is achieved by reducing the void ratio, which can be reached with the addition of chicken feather keratin structures to the expansive soil. Finally, the mechanism by which discrete and randomly distributed fibers reduce swelling pressure of expansive soil is explained.
\end{abstract}

\section{Introduction}

In the field of geotechnical engineering, it has long been known that swelling of expansive soils caused by moisture change results in significant distresses and hence in severe damage to overlying structures. Shrinking and swelling are aggravated by wide swings in the water content, which are due to climatic conditions and wide variations in the rainfall; in addition expansive clays soils are extensively distributed worldwide [1]. These facts cause severe safety and economic problems [2]. For instance, the annual cost of damage is estimated to be around $\$ 1000$ million in the USA [3].
Therefore, searching for responses to this problem is highly relevant from several points of view.

An interesting alternative is the stabilization of expansive soils by using additives such as lime, fly ash, or cement, which is well documented $[1,4-6]$. In recent years, discrete fibers have been added and mixed into soils to improve their strength behavior [3, 7-11]. Unfortunately the interaction mechanisms between reinforcements and soil are complex and depend on their specific features and are necessary to study [12]. An adequate model is presented by Tang et al. [13]; they considered that the bonding force between the fiber and the contact area of soil particles contributes to the 
TABLE 1: Natural fibers used as reinforcement for modified soils.

\begin{tabular}{|c|c|c|c|}
\hline Natural fiber & Percentage & Effect of reinforcement & Reference \\
\hline \multirow[t]{2}{*}{ Coconut (coir) } & $\begin{array}{l}\text { Data not included in } \\
\text { reference }\end{array}$ & Reducing the swelling tendency of the soil. & [9] \\
\hline & $0.5,1.0,1.5$, and 2 & Reducing the resilient strain for soils. & [15] \\
\hline \multirow[b]{2}{*}{ Sisal } & 4 & $\begin{array}{l}\text { Imparted considerable ductility and also increasing slightly } \\
\text { its compression strength. Prevention of shrinkage cracks due } \\
\text { to the drying process. }\end{array}$ & {$[16]$} \\
\hline & $0.25,0.5,0.75$, and 1 & $\begin{array}{l}\text { Reduces the dry density of the soil due to a low specific } \\
\text { gravity and unit weight of sisal fiber. The shear stress is } \\
\text { increased nonlinearly with increase in length of fiber. } \\
\text { Increase in length reduces the shear stress. Cohesion is } \\
\text { increased. }\end{array}$ & {$[17]$} \\
\hline Palm & 0.25 and 0.5 & $\begin{array}{l}\text { Cohesion increases linearly with fiber content. The increase } \\
\text { in the length of fiber increases the value of internal friction } \\
\text { angle. Coating fibers increase the shear strength of the soil. }\end{array}$ & {$[18]$} \\
\hline \multirow[b]{2}{*}{ Jute } & $0.25,0.5,0.75$, and 1 & $\begin{array}{l}\text { Contributes to the resilient modulus of native soil under the } \\
\text { freezing and thawing conditions. }\end{array}$ & {$[19]$} \\
\hline & 0.2 to 1 & $\begin{array}{l}\text { Reduces the maximum dry density while increasing the } \\
\text { optimum moisture content. California Bearing Ratio value is } \\
\text { increased more than } 2.5 \text { times. }\end{array}$ & {$[9]$} \\
\hline Flax & 0.6 and 0.8 & $\begin{array}{l}\text { Enhances the ductility of the material and eliminates the } \\
\text { catastrophic failure pattern displayed by specimens without } \\
\text { fiber-reinforcement. } \\
\text { An enamel paint coating was applied to the fiber surface to } \\
\text { increase its interfacial bond strength with the soil. }\end{array}$ & {$[20]$} \\
\hline Barely straw & 1 & $\begin{array}{l}\text { Decreasing shrinkage, reducing the curing time, and } \\
\text { enhancing compressive strength. Flexural and shear } \\
\text { strengths were also increased and more ductile. }\end{array}$ & {$[9]$} \\
\hline Bamboo & $\begin{array}{l}\text { Data not included in } \\
\text { reference }\end{array}$ & $\begin{array}{l}\text { The root rhizomes of bamboo are excellent soil binders which } \\
\text { can prevent erosion. }\end{array}$ & {$[9,21]$} \\
\hline Hay & $0.5,1$, and 1.5 & $\begin{array}{l}\text { The dry density decreases. The optimum water content, the } \\
\text { unconfined compression strength, shrinkage limit, and the } \\
\text { swelling decrease with increasing hay addition. }\end{array}$ & {$[22]$} \\
\hline
\end{tabular}

interfacial shear resistance. In addition when shear occurs, the interfacial friction also is conditioned by the resistance of soil particle rearrangement and rotation. Besides, an important parameter in expansive soils is the water interaction; this fact is also contemplated by Tang et al. [13], and in this case pore water-fiber contact area also exerts certain influence on the interfacial shear resistance, which could be strongly dependent on the hydrophilic behavior of reinforcement material.

On the other hand, the plastic behavior of fibers also has an interesting effect, since during compaction hard particles in soil can produce deformation of fiber body. This was reported as an additional parameter to take into account since pits and deformations result in an increase in fiber surface roughness an interfacial interlock force [13]. The above considerations are especially important in soil stabilization with natural materials, which recently have received a great attention in reinforcement of soils with natural fibers. In Table 1 some natural fibers used to change the properties of soils and their effects are presented. Then, as it can be observed, in nature, it is possible to find an almost infinite source of high performance materials which are still waiting for serious studies to establish them as basis for innovative technologies and useful raw materials.

In addition to vegetal reinforcements, fibers from animal origin can be also considered to modify soil properties. This is the case of keratin structures from different animal sources, such as wool and feathers. Keratin is durable, insoluble in the majority of organic solvents, and chemically unreactive, being thus suited to exposure to severe environmental conditions, as can be observed in hair, wool, and feathers. Keratin also provides mechanical strength and elasticity since these are important inherent properties from this fibrillar protein [14].

In the civil engineering field, keratin has found recently interesting research opportunities. For instance, Petric-Gray et al. [10] applied wool to stabilize soils used in the building industry. They used two different percentages, 0.25 and 0.5 , in order to modify soil properties. From their results it was observed that wool stabilized soil increases the compressive strength considerably compared with unstabilized soils. Similarly, Galán-Marín et al. [23] studied the stabilization of soils with natural polymers (alginate) and fibers from sheep's wool ( 0.25 and $0.5 \%)$ to produce a composite; their results show that the addition of alginate separately increases compression 
strength from 2.23 to $3.77 \mathrm{MPa}$ and the addition of wool fiber increases compression strength until 37\%. Aymerich et al. [24] investigated the improvements in strength and crack resistance induced by the introduction of 2 and $3 \%$ of wool fibers in an earthen material. They show that fibrous reinforcement greatly improved residual strength, ductility, and energy absorption of the reinforced material as compared to unreinforced soil. The results of the study also show that fiber length had a notable influence on the postfracture response of the material at large deformation regimes.

The results using keratin from wool are encouraging; therefore an extensive research field can be predicted in this way. However two important facts deserve to be noted. Firstly wool is a raw material for the textile industry and only a minimal quantity of residues could be used for this purpose. In the second place, it is important to consider that countries such as Scotland or Australia are rich wool producers, but there are others that produce very few quantities of this textile but instead are important consumers of poultry meat. Poultry feathers are considered as a worldwide waste causing serious environmental problems. The feathers, from where keratin fibers can be obtained, have been considered not only a waste, but rather a complicated disposal challenge, in spite of their important characteristics. Keratin, from poultry feathers, is a fibrillar protein that has high stability due to its selfassembled hierarchical structure [25]; in addition feathers have different structural arrangement depending on which part is observed: barbs and barbules, rachis, or quill. Internal structure of feathers rachis was described by Meyers et al. [26]. They observed a cellular core limited by a solid wall, inside an intricate arrangement, similar to a foam, constituting the internal cells. But even these cells are not solid; they are formed by a network of fibers with $200 \mathrm{~nm}$ in diameter.

On the other hand, Martínez-Hernández et al. [14] identified that central barbs are hollow and have an irregular, noncylindrical shape [14], whereas barbules are completely full and without free voids inside [27]. This structural dissimilarity provides different mechanical behavior to the feathers [28], which is reflected in the interaction with polymeric matrix, giving a significant variability in thermomechanical response depending on the type and quantity of feather segment reinforcement [29]. Taking into account this influence, we propose that feather segments can contribute positively as reinforcement in expansive soil, considering also that their structural features could produce different effects on mechanical response. Thus this natural material could be applied in soil stabilization and decrease their expansive potential, contributing to the effort to diminish the harmful damage that swelling soils can cause in buildings and constructions.

\section{Materials and Methods}

\subsection{Materials}

2.1.1. Chicken Feather Segments. Feather segments were obtained from chicken feathers by the following procedure. After leaving the poultry processing plant, feathers were washed with ethanol and water and finally were dried with an air stream; this allows having clean, sanitized, and
TABLE 2: Index properties of the expansive soil.

\begin{tabular}{lccl}
\hline Parameter & Symbol & Value & Norma \\
\hline Water content & $\omega$ & $27.86(\%)$ & ASTM D2216-98 [30] \\
Unit weight & $\gamma_{m}$ & $1.69\left(\mathrm{~T} / \mathrm{m}^{3}\right)$ & ASTM D7263-09 [31] \\
Specific gravity & $S_{s}$ & 2.67 & ASTM D854-02 [32] \\
Void ratio & $e$ & 1.32 & ASTM D7263-09 [31] \\
Degree of saturation & $G_{w}$ & $75.99(\%)$ & ASTM D7263-09 [31] \\
Gravel & $\mathrm{G}$ & $0.00(\%)$ & ASTM D2487-00 [33] \\
Sand & $\mathrm{S}$ & $2.00(\%)$ & ASTM D2487-00 [33] \\
Fine & $\mathrm{C}$ & $98.00(\%)$ & ASTM D2487-00 [33] \\
Liquid limit & $\mathrm{LL}$ & $85.51(\%)$ & ASTM D4318-00 [34] \\
Plastic limit & $\mathrm{LP}$ & $33.19(\%)$ & ASTM D4318-00 [34] \\
Plasticity index & $\mathrm{Ip}$ & $52.32(\%)$ & ASTM D4318-00 [34] \\
Shrinkage limit & $\mathrm{SL}$ & $14.51(\%)$ & ASTM D427-04 [35] \\
Classification & $\mathrm{USCS}$ & $\mathrm{CH}$ & ASTM D2487-00 [33] \\
\hline
\end{tabular}

odor-free raw material. Then, dried feathers were cut with blades and separated in three segments: barbs (B), rachis or quill (Q), and partially cut feathers which include barbs and quill mixed $(\mathrm{T})$; this last one was called total fiber.

2.1.2. Expansive Soil. The natural soil used for this study is active natural clay obtained from Santa Fe, Queretaro, Mexico, located at $20^{\circ} 35^{\prime} 12.21^{\prime \prime} \mathrm{N}-100^{\circ} 26^{\prime} 50.65^{\prime \prime} \mathrm{W}$ (about $5 \mathrm{~km}$ south of Queretaro City). The climate is considered as semidesert with $780.3 \mathrm{~mm}$ of water rain in 2013. Expansive soil samples were obtained from an open cut on the site, sheltered in plastic bags, and transported to the laboratory to be tested. The bags were filled separately with soil samples taken from $0.60 \mathrm{~m}$. Based on the plasticity properties, the soil was classified as $\mathrm{CH}$ (clay with high plasticity), according to the Unified Soil Classification System (USCS). The physical properties of soil are given in Table 2. All the experimental determinations of physical properties were realized according to ASTM procedures as is indicated. The mineralogical composition of constituents of the soil, investigated using $\mathrm{X}$-ray diffraction analysis, reveals that the predominant clay minerals are montmorillonite with minor amounts of illite.

\subsection{Methods}

2.2.1. Sample Preparation. Dry soil was initially conditioned with water in order to maintain the natural features of unit weight and moisture; for this, dry soil samples were mixed with water corresponding to the natural moisture. After, wet soil samples were mixed separately with three kinds of feather segments: quill, barbs, and partially cut feathers (total fiber). These segments are shown in Figure 1. Four different contents of feather segments were used as soil modifiers: $0.25,0.50$, 1.00 , and $3.00 \mathrm{wt} \%$; additionally soil without modification was maintained as control sample. Once mixed, the feather segments-soil samples were preserved at room temperature until they were required for the different analysis. The nomenclature used for each sample is described in Table 3.

2.2.2. Tests Conducted. One-dimensional swell-consolidation tests were performed on compacted mixtures of fibers 
TABLE 3: Nomenclature adopted for feather segments-soil mixtures.

\begin{tabular}{lcc}
\hline Type of fiber & $\begin{array}{c}\text { Feather segment } \\
\text { (wt } \%)\end{array}$ & Nomenclature \\
\hline Natural Soil & 0.00 & SN \\
Barbs & 0.25 & SMB-0.25\% \\
Barbs & 0.50 & SMB-0.5\% \\
Barbs & 1.00 & SMB-1\% \\
Barbs & 3.00 & SMB-3\% \\
Quill & 0.25 & SMQ-0.25\% \\
Quill & 0.50 & SMQ-0.5\% \\
Quill & 1.00 & SMQ-1\% \\
Quill & 3.00 & SMQ-3\% \\
Total fiber & 0.25 & SMT-0.25\% \\
Total fiber & 0.50 & SMT-0.5\% \\
Total fiber & 1.00 & SMT-1\% \\
Total fiber & 3.00 & SMT-3\% \\
\hline
\end{tabular}

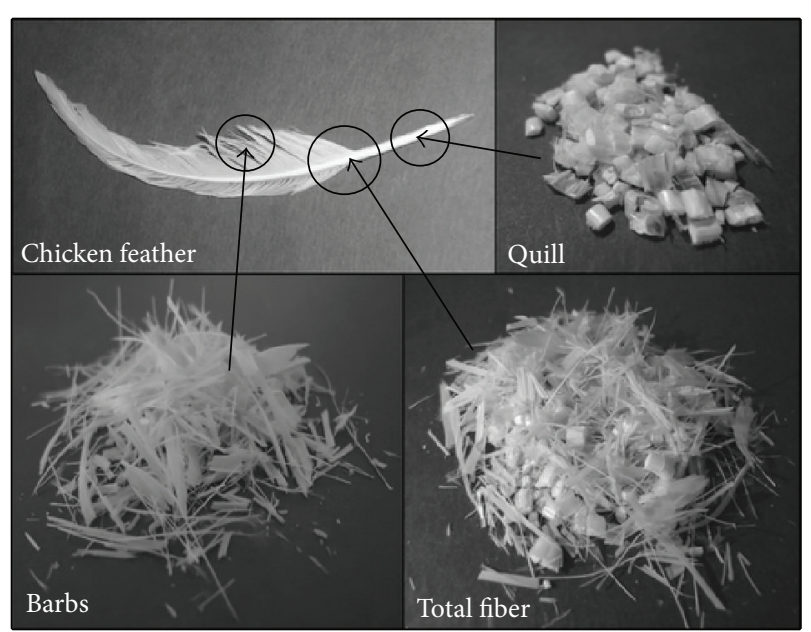

FIGURE 1: Kinds of feather segments: quill, barbs, and partially cut feathers (total fiber).

and expansive soil to assert the optimum fiber content and aspect ratio for maximum heave reduction. Swell-consolidation tests were conducted in a conventional oedometer (Controls model 26-T0326) with $75 \mathrm{~mm}$ in diameter and $20 \mathrm{~mm}$ in thickness $(H)$. The specimens (feather segmentssoil) were statically compacted inside the oedometer ring by stacking three layers, each one around $7 \mathrm{~mm}$ in thickness, to ensure uniform density. In all samples, a random distribution of fiber was maintained. For each sample, heave was allowed under a seating surcharge of $1 \mathrm{kPa}$ by free inundation or by allowing water continuously into the soil specimen. After final heave $(\Delta H)$ was reached, the sample was compressed with incremented vertical loads until initial void ratio (e) was attained. Swelling pressure $\left(p_{s}\right)$ was determined as the pressure corresponding to the initial void ratio $(e)$ of the specimens; the $p_{s}$ values were obtained from the $e$-log $p$ curve depicted for each type of feather segment used as modifier. These evaluations were made following the standard test

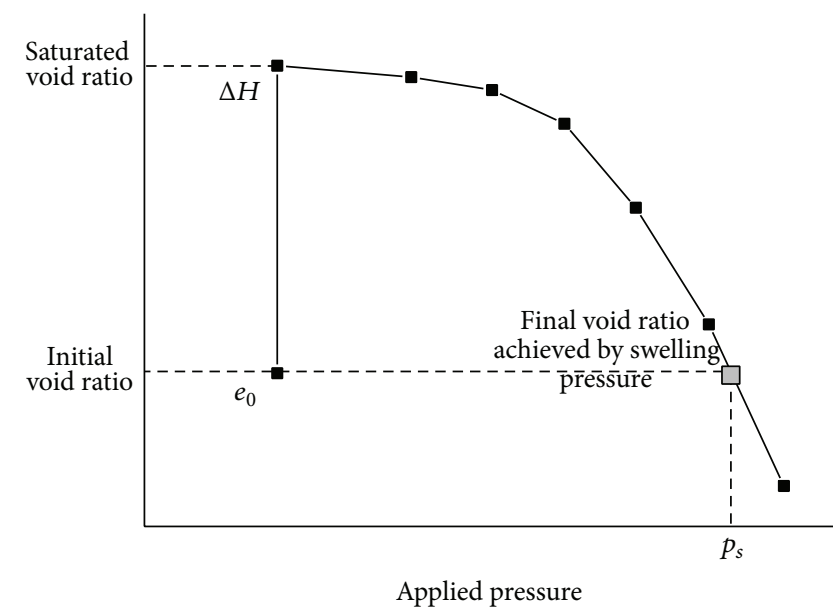

FIGURE 2: Graphic explanation of swelling pressure.

methods ASTM D4546-03 [36]. The swelling pressure $\left(p_{s}\right)$ corresponds to the necessary value to return soil sample towards its initial void ratio after it was completely saturated with water. Figure 2 shows a graphic explanation of the method followed to establish the swelling pressure and its relation with void ratios.

Specific surface area (SSA) of soils is a very important index soil property since it is directly related to the amount of expansion [37, 38]. It can be calculated by determining the amount of an adsorbed substance such as methylene blue $(\mathrm{MB})$, ethylene glycol monoethyl ether, or water required to form a monolayer [39]. In this research SSA was determined using $\mathrm{MB}$; the tests were realized in samples modified with the feather segments at the weight percentages described in Table 3. This test was realized in basis to the norm AASHTO TP 57-06 [40].

The shrinkage limit (SL) is an important parameter for expansive soils due to the fact that it represents the water content in soil, which through a dry process does not undergo any change in volume. The procedure to determine this parameter was according to ASTM D427-04 [35] method.

The modified soils with $3 \mathrm{wt} \%$ of feather segments were analyzed by scanning electron microscopy (SEM) in a JEOL model SM-6060LV microscope at $5-20 \mathrm{kV}$ and high vacuum. Before analyzing the morphological surface, the soil samples were fastened to a double-sided adhesive tape attached to copper stubs and vacuum-coated with gold at $7 \times 10^{-2} \mathrm{mBar}$ using Argon in a Sputter Coater EMS 550 with a final coat of $120 \mathrm{~nm}$. Soil samples with $3 \mathrm{wt} \%$ of feather segments were chosen for SEM analysis due to the fact that these samples have more feasibility to found zones with feather-soil interactions.

\section{Results and Discussion}

The value of void ratio depends on volumetric changes of soils; then in order to evaluate the effect of keratin over these parameters in soils, void ratios were studied in all samples as well as swelling pressure. Figure 3 shows the void ratio curves as function of log of applied pressure for natural soil and 


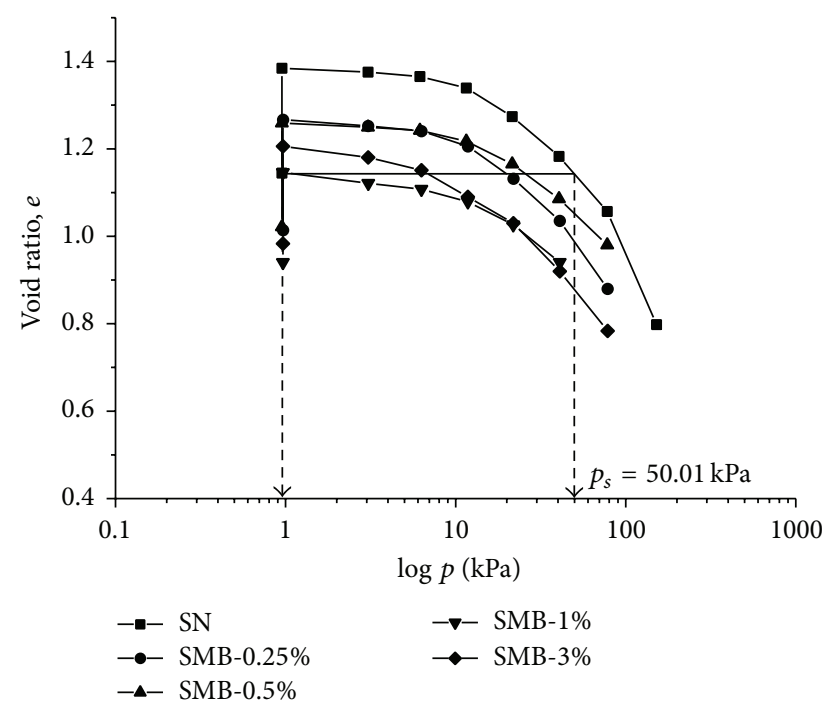

FIGURE 3: $e-\log p$ curves of soil modified with barb fibers.

TABLE 4: $p_{s}$ and $G_{w}$ values presented by soil modified with barbs.

\begin{tabular}{lcc}
\hline Type of soil & $p_{s}(\mathrm{kPa})$ & $G_{w}(\%)$ \\
\hline SN & 50.01 & 64.63 \\
SMB- $0.25 \%$ & 45.03 & 69.70 \\
SMB- $0.5 \%$ & 61.71 & 68.93 \\
SMB-1\% & 41.11 & 71.61 \\
SMB-3\% & 28.01 & 67.86 \\
\hline
\end{tabular}

for samples modified with barb fibers varying the contents. In this graph it is possible to appreciate that keratin barbs diminish the values of pressure needed to return to initial void ratio in the soil, since all curves with modified soils are below the natural soil. The curve in which $p_{s}$ presents the lower value corresponds to soil with $3 \mathrm{wt} \%$ of barb fibers. In addition, it is also important to observe that the initial void ratio (e) for the modified soils is lower than $e$ for natural soil (all the values for $e$ are shown in Table 4). This variation is due to the influence of keratin barbs exerted on soils, since unit weight and moisture were reproduced in modified soils as they were obtained in soil in situ; therefore no changes in this sense are expected due to the effect of these control parameters. This diminishing in $e$ values is because the specific gravity is smaller for barb fibers (0.796) [41] than for soil sample (1.69) and these keratin materials occupy the voids which were previously occupied by air, decreasing the volume of voids and increasing the volume of solids in the total volume.

In Figure 3, it is also appreciated that swelling pressure $\left(p_{s}\right)$ decreases as the fiber content is increased. The corresponding values of $p_{s}$ for the modified soils are shown in Table 4. This behavior is due to the fact that barb fibers are hydrophobic and their internal structure is compact and close [14]. These features do not allow the fact that fibers can absorb water. In spite of the fact that barbs can produce a decreasing in swelling pressure, the inherent characteristics and variability of the natural material are reflected in the

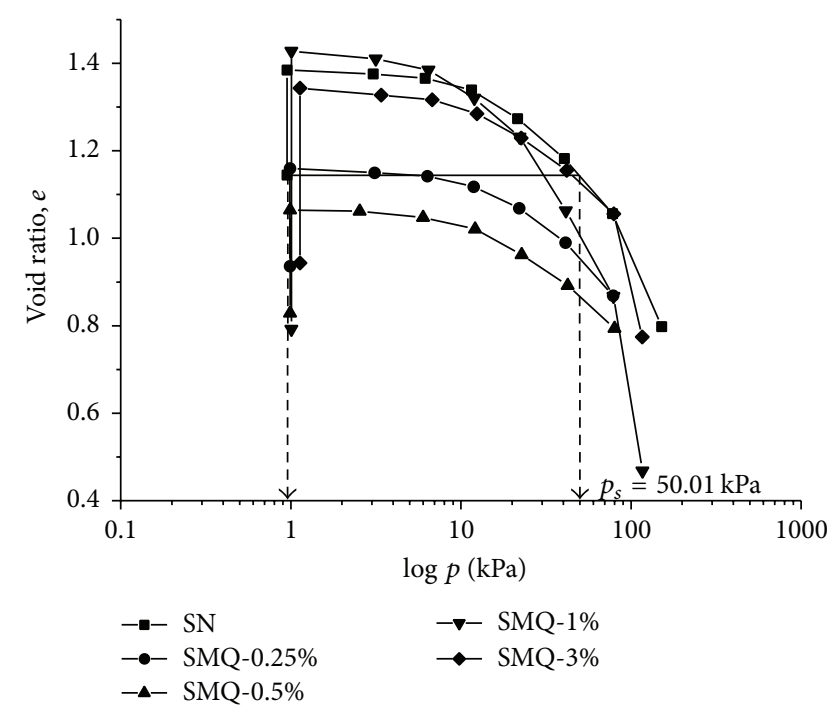

FIGURE 4: $e-\log p$ curves of soil modified with quill segments.

absence of a clear tendency according to the increment of concentration of barb fiber.

The effect caused by hydrophobic nature of keratin barbs is also observed in the initial degree of saturation values $\left(G_{w}\right)$, showed in Table 4 . These are slightly higher for the modified soils than for that corresponding to the natural soil, which is in agreement with $e$ results and is related also with the specific gravity. Take into account the so-called basic volume-mass relationship for soils that establishes [42]

$$
G_{w} e=\omega S_{s},
$$

where $G_{w}$ corresponds to initial degree of saturation, $e$ is initial void ratio, $\omega$ is water content, and $S_{s}$ is specific gravity. This equation implies that $G_{w}$ can be considered as the inverse of $e$.

In our samples, specific gravity diminishes as fiber contents are increased as it is shown in Table 4, and this is reflected in $G_{w}$ response. In addition, the increasing in $G_{w}$ values is explained considering that modified soils were obtained first by dry weight of keratin barb and soil; later the necessary quantity of water to maintain $28 \%$ of water content was added to a complete saturation of the sample. Therefore as fiber content is increased, a lower quantity of soil is included, and this must absorb all the added water; besides the minimum interaction between keratin fiber and water due to the hydrophobic character of keratin feathers [14] must be considered.

Figure 4 shows the $e$ - $\log p$ curves for the natural soil sample and for samples modified with quill varying the contents with $0.25,0.50,1.00$ or $3.00 \mathrm{wt} \%$. In this figure the void ratio performance was similar to that presented by soil modified with barbs. However, this type of segment had a higher swelling pressure in all cases, compared to natural soil, as can be observed in Table 5. This is due to the fact that quill segments have an internal structure like a honeycomb (Figure 5). This particular morphology allows an internal adsorption of water, which means that soil could have access 


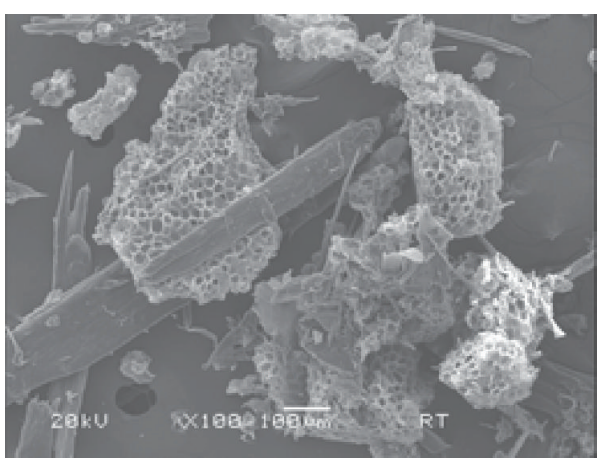

(a)

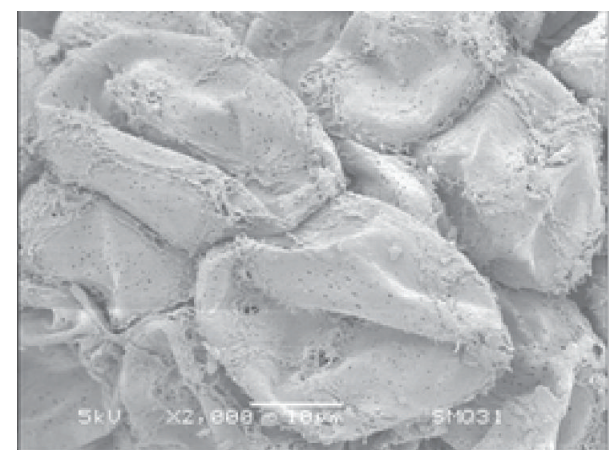

(b)

FIGURE 5: SEM micrographs of quill to 100x (a) and 2000x (b).

TABLE 5: $p_{s}$ and $G_{w}$ values presented by soil modified with quill.

\begin{tabular}{lcc}
\hline Type of soil & $p_{s}(\mathrm{kPa})$ & $G_{w}(\%)$ \\
\hline SN & 50.01 & 64.63 \\
SMQ-0.25\% & 54.75 & 72.80 \\
SMQ-0.5\% & 65.23 & 81.27 \\
SMQ-1\% & 86.47 & 76.18 \\
SMQ-3\% & 92.58 & 70.50 \\
\hline
\end{tabular}

to the retained water inside the quill. Thus soil modified with quill has the possibility to use this water and avoid the volumetric changes that expansive soils undergo during dry seasons. It is worthy to mention that quill fragments are also easily collapsed and because of their empty cells have even lower values in specific gravity than barbs, as it is observed in Table 5.

Table 5 shows the values corresponding to $p_{s}$ and $G_{w}$ for soil modified with quill. As it is observed the $p_{s}$ value for soil modified with $0.25 \mathrm{wt} \%$ of quill segment is the closest to the natural soil; then taking into account this parameter the most recommendable modification for this series is with $0.25 \mathrm{wt} \%$ of quill.

The corresponding $G_{w}$ values were higher than that observed for natural soil, a similar behavior observed also for soil modified with barbs. As can be perceived the $G_{w}$ values are even higher for quill as modifier than those for barbs. This performance is completely logic if the honeycomb structure of quill is considered, since due to this internal structure free voids are more evident.

The $e-\log p$ curves for samples modified with total fibers are showed in Figure 6. These samples have a better performance than soil modified with quill, but not as good as soil modified with barbs.

As in the other two modifications, the void ratios of modified soils are smaller than the value determined for natural soil (Figure 6), and as it is observed in Table 6 the smaller value for $p_{s}$ corresponds to the sample with $0.25 \mathrm{wt} \%$ of total fiber included. It is noteworthy that this is even smaller than natural soil. Regarding the $p_{s}$ of the other samples with total fiber, the values observed were very close

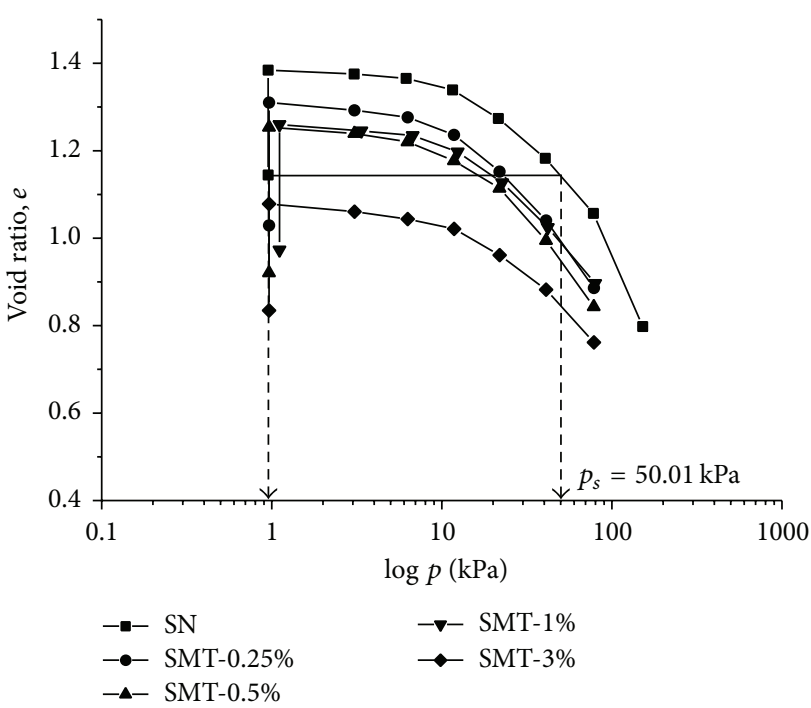

FIGURE 6: $e-\log p$ curves of soil modified with total fiber feathers.

TABLE 6: $p_{s}$ and $G_{w}$ values presented by soil modified with total feathers.

\begin{tabular}{lcc}
\hline Type of soil & $p_{s}(\mathrm{kPa})$ & $G_{w}(\%)$ \\
\hline SN & 50.01 & 64.63 \\
SMT-0.25\% & 43.76 & 60.89 \\
SMT-0.5\% & 56.11 & 69.82 \\
SMT-1\% & 54.84 & 66.46 \\
SMT-3\% & 50.96 & 74.80 \\
\hline
\end{tabular}

to natural soil; despite the fact that they are larger, the general performance is acceptable.

Table 6 also presents the corresponding values of $G_{w}$, as it can be appreciated that only the value for $3 \mathrm{wt} \%$ of total fiber included has a very dissimilar behavior, since its value is $13.60 \%$ higher. This unusual value can be attributed to the honeycomb structure and the free voids, which in this sample could be more abundant according to the higher percentage of quill segments included as part of total fiber. This behavior is nonhomogeneous due to the fact that 


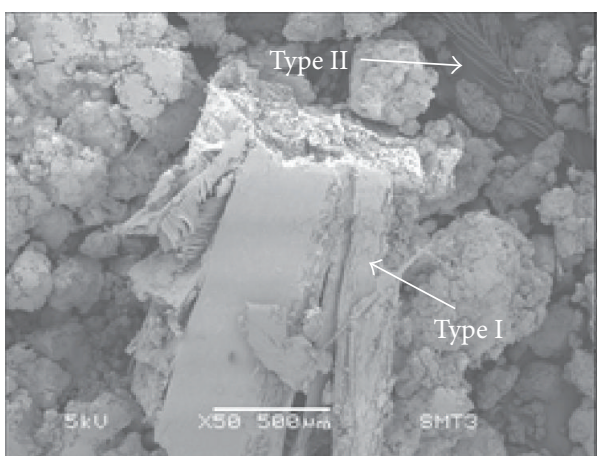

(a)

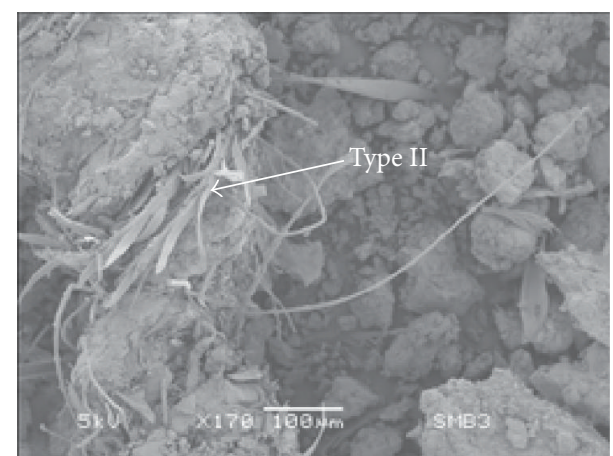

(b)

FIGURE 7: SEM micrographs of modified soil with total fibers 50x (a) and barbs 170x (b).

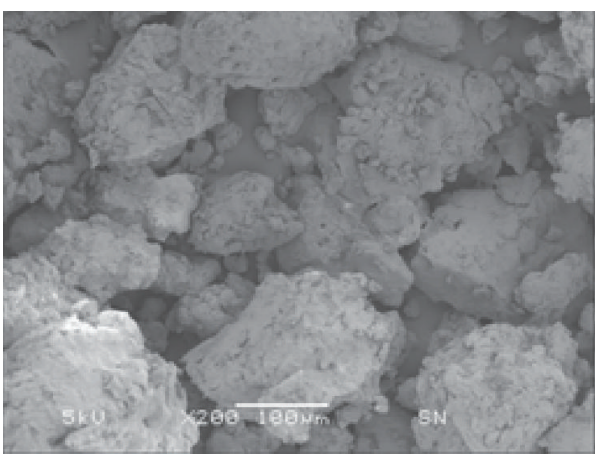

(a)

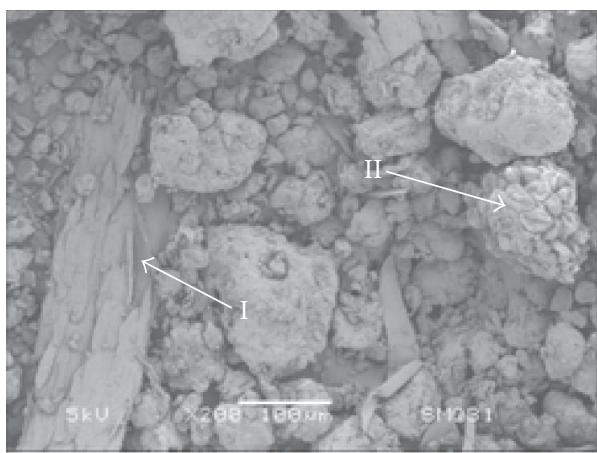

(c)

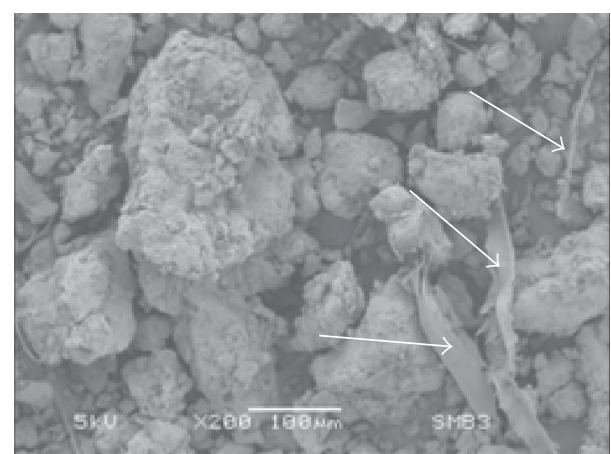

(b)

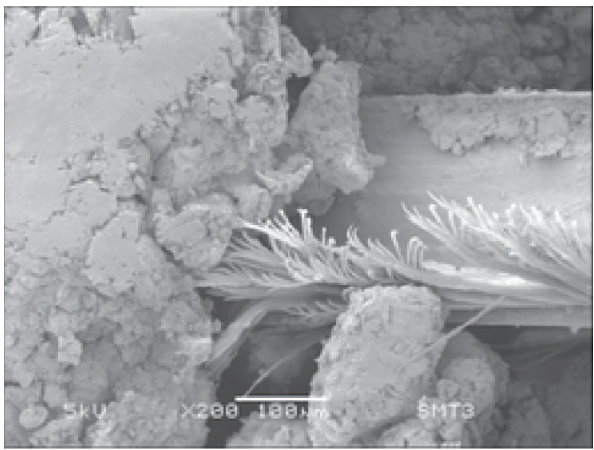

(d)

FIGURE 8: SEM micrographs of SN (a); SMB-3\% (b); SMQ-3\% (c); and SMT-3\% (d).

reinforcement is a natural material, and its structure can vary causing unexpected responses.

The internal structures of quill segment were observed in Figure 5, and additionally Figure 7(a) shows a SEM image of total fiber segment included in the soil modified with $3 \mathrm{wt} \%$. This figure shows two different types of structures; one is a clear segment of quill with some fine barbs attached, indicated as type I. This has the honeycomb structure. Type II can be considered similar to the hierarchical morphology shared by barbs in Figure 7(b).

The SEM micrographs presented in Figure 8 show the physical distribution of feather segments in soil. All samples have the characteristic lumps observed in natural soil
(Figure 8(a)), which interact with feather segments depending on their shape and size. Among the three keratin materials studied, barbs are the most uniform and thinnest material used to modify the soil; consequently they were perfectly covered by lumps, as can be observed by the fibers signed by arrows in Figure $8(\mathrm{~b})$. This interaction is similar to that presented by Tang et al. [13] and represented in their model. In contrast quill and total fiber present a wide variety of forms and sizes. For instance, quill is fragmented producing segments from the outer cortex (indicated as I in Figure 8(c)) and the internal structure (II in Figure 8(c)). Both have different grade of interaction with soil, since their morphology is a key parameter, as it was described taking into account the 


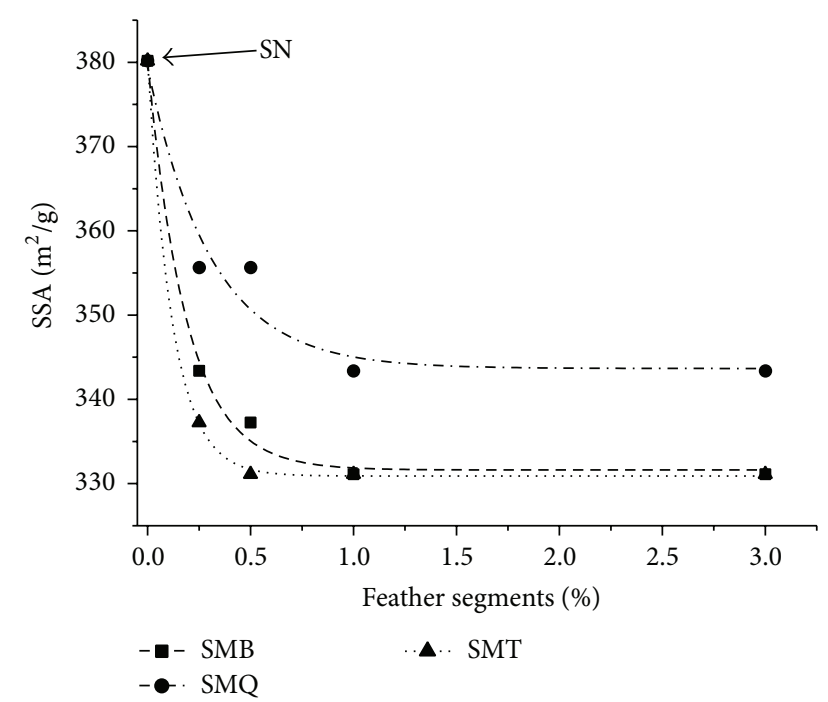

FIGURE 9: Specific surface areas (SSA) for the different percentages of keratin segments used as soil modifiers.

honeycomb structure. The presence of fine fibers and quill in the total fiber is a useful advantage in the adhesion of fine particles of soil over the surface of total fiber as can be appreciated in Figure 8(d). The morphological features and interaction between the three types of segments and soil are reflected in final swelling properties, since soil modified with barbs shows the highest degree of modification as was discussed before.

Taking into account that specific surface area of soils (SSA) is an important parameter to quantify interaction processes at the liquid-solid interface [43], it is very useful to corroborate the results explained above, since SSA is related to the capability of soil to adsorb water and therefore involves free swell index and liquid limit of soil [39]. Thus, if SSA values are high, then the expansive potential is higher too. The SSA results obtained from natural soil and soil modified with the three types of feather segments are showed in Figure 9. It is clearly appreciated that SSA values decrease as the percentage in keratin segments is increased. In addition the type of segments also has a noticeable effect on the SSA behavior. Total fiber and barbs have similar tendencies, although the lowest value was obtained with total fiber. The soil modified with quill presents the highest values; this is consequence of the free voids observed in the internal structure that can retain water as was explained before.

\section{Conclusions}

In agreement with the results obtained in the oedometer (e-log $p$ curves), it was concluded that soils modified with barbs present the lower values in swelling pressure. The soil modified with $3 \%$ of barbs has a value of $28.01 \mathrm{kPa}$; this is the smallest value found in our soil samples, and it represents a reduction of $44 \%$ in swelling pressure compared to natural soil without reinforcement.

On the other hand, void ratio is also an important parameter, since if it decreases the possible expansion is also diminished. This response is produced due to the fact that the space between the particles is reduced and the possibility to infiltrate water is also reduced. In this case, the behavior of void ratio is strongly influenced by the structural features of feather segments, since quill fragments are hollow. Thus the order of initial void ratio behavior was quill $>$ total fiber $>$ barbs $>$ natural soil.

Modification with quill also provides a good performance taking into account the results of degree of saturation. Higher values reached for this parameter imply that soil is less susceptible to undergoing harmful expansion. The results allow observing that general performance of degree of saturation was following the next order: quill $>$ barbs $>$ total fiber $>$ natural soil.

On the other hand, specific surface area results show also a better behavior for soil modified with feather segments, since all modified samples present lower values than natural soil.

Therefore it is possible to conclude that the proven feather segments effectively can be used as ecological modifiers for expansive soils, taking advantage of this structural material obtained from chicken feathers and changing natural properties of soil.

\section{Conflict of Interests}

The authors declare that there is no conflict of interests regarding the publication of this paper.

\section{Acknowledgments}

The authors are grateful to M. Sc. Alicia del Real López for her technical assistance in SEM micrographs, to Centro de Geociencias, UNAM, and to Dr. Mariana Vega-González for her assistance in X-Ray diffraction analysis. Financial support from CONACyT, as Ph.D. Scholarship, is gratefully acknowledged by Elda Montes-Zarazúa. Article: In memoriam Dr. Adolfo M. Espíndola-González (1977-2014).

\section{References}

[1] A. Seco, F. Ramírez, L. Miqueleiz, and B. García, "Stabilization of expansive soils for use in construction," Applied Clay Science, vol. 51, no. 3, pp. 348-352, 2011.

[2] B.-T. Wang, C.-H. Zhang, X.-L. Qiu, E.-Y. Ji, and W.-H. Zhang, "Research on wetting-drying cycles' effect on the physical and mechanical properties of expansive soil improved by OTACKCl," Advances in Materials Science and Engineering, vol. 2015, Article ID 304276, 7 pages, 2015.

[3] B. V. S. Viswanadham, B. R. Phanikumar, and R. V. Mukherjee, "Swelling behaviour of a geofiber-reinforced expansive soil," Geotextiles and Geomembranes, vol. 27, no. 1, pp. 73-76, 2009.

[4] W.-H. Zhang, H.-W. Zheng, J.-W. Qi, and B.-T. Wang, "Experimental study on the feasibility of using water glass and aluminum sulfate to treat complications in high liquid limit soil subgrade," Advances in Materials Science and Engineering, vol. 2015, Article ID 457978, 7 pages, 2015.

[5] H. Nowamooz and F. Masrouri, "Volumetric strains due to changes in suction or stress of an expansive bentonite/silt mixture treated with lime," Comptes Rendus-Mecanique, vol. 338, no. 4, pp. 230-240, 2010. 
[6] A. A. Al-Rawas, A. W. Hago, and H. Al-Sarmi, "Effect of lime, cement and sarooj (artificial pozzolan) on the swelling potential of an expansive soil from Oman," Building and Environment, vol. 40, no. 5, pp. 681-687, 2005.

[7] Y. Wu, Y. Li, and B. Niu, "Assessment of the mechanical properties of sisal fiber-reinforced silty clay using triaxial shear tests," The Scientific World Journal, vol. 2014, Article ID 436231, 9 pages, 2014.

[8] A. Hamidi and M. Hooresfand, "Effect of fiber reinforcement on triaxial shear behavior of cement treated sand," Geotextiles and Geomembranes, vol. 36, pp. 1-9, 2013.

[9] S. M. Hejazi, M. Sheikhzadeh, S. M. Abtahi, and A. Zadhoush, "A simple review of soil reinforcement by using natural and synthetic fibers," Construction and Building Materials, vol. 30, pp. 100-116, 2012.

[10] J. Petric-Gray, C. Galán-Marín, C. Rivera-Gómez, R. Rodríguez-García, and P. Osta-Fort, "On soil stabilization with alginate and wool for construction industry," in Proceedings of the 11th International Conference on Non-conventional Materials and Technologies (NOCMAT '09), Bath, UK, September 2009.

[11] B. R. George, A. Evazynajad, A. Bockarie, H. McBride, T. Bunik, and A. Scutti, "Keratin fiber nonwovens for erosion control," in Natural Fibers, Plastics and Composites, F. T. Wallenberger and N. E. Weston, Eds., pp. 67-81, Springer, New York, NY, USA, 2004.

[12] S. Huang, X. Ding, Y. Zhang, and W. Cheng, “Triaxial test and mechanical analysis of rock-soil aggregate sampled from natural sliding mass," Advances in Materials Science and Engineering, vol. 2015, Article ID 238095, 14 pages, 2015.

[13] C.-S. Tang, B. Shi, and L.-Z. Zhao, "Interfacial shear strength of fiber reinforced soil," Geotextiles and Geomembranes, vol. 28, no. 1, pp. 54-62, 2010.

[14] A. L. Martínez-Hernández, C. Velasco-Santos, M. de Icaza, and V. M. Castaño, "Microstructural characterisation of keratin fibres from chicken feathers," International Journal of Environment and Pollution, vol. 23, no. 2, pp. 162-178, 2005.

[15] M. S. Chauhan, S. Mittal, and B. Mohanty, "Performance evaluation of silty sand subgrade reinforced with fly ash and fibre," Geotextiles and Geomembranes, vol. 26, no. 5, pp. 429-435, 2008.

[16] K. Ghavami, R. D. Toledo Filho, and N. P. Barbosa, "Behaviour of composite soil reinforced with natural fibres," Cement and Concrete Composites, vol. 21, no. 1, pp. 39-48, 1999.

[17] J. Prabakar and R. S. Sridhar, "Effect of random inclusion of sisal fibre on strength behaviour of soil," Construction and Building Materials, vol. 16, no. 2, pp. 123-131, 2002.

[18] F. Ahmad, F. Bateni, and M. Azmi, "Performance evaluation of silty sand reinforced with fibres," Geotextiles and Geomembranes, vol. 28, no. 1, pp. 93-99, 2010.

[19] H. Güllü and A. Khudir, "Effect of freeze-thaw cycles on unconfined compressive strength of fine-grained soil treated with jute fiber, steel fiber and lime," Cold Regions Science and Technology, vol. 106-107, pp. 55-65, 2014.

[20] M. Segetin, K. Jayaraman, and X. Xu, "Harakeke reinforcement of soil-cement building materials: manufacturability and properties," Building and Environment, vol. 42, no. 8, pp. 3066-3079, 2007.

[21] D.-G. Lin, B.-S. Huang, and S.-H. Lin, "3-D numerical investigations into the shear strength of the soil-root system of Makino bamboo and its effect on slope stability," Ecological Engineering, vol. 36, no. 8, pp. 992-1006, 2010.
[22] A. E. M. K. Mohamed, "Improvement of swelling clay properties using hay fibers," Construction and Building Materials, vol. 38, pp. 242-247, 2013.

[23] C. Galán-Marín, C. Rivera-Gómez, and J. Petric, "Clay-based composite stabilized with natural polymer and fibre," Construction and Building Materials, vol. 24, no. 8, pp. 1462-1468, 2010.

[24] F. Aymerich, L. Fenu, and P. Meloni, "Effect of reinforcing wool fibres on fracture and energy absorption properties of an earthen material," Construction and Building Materials, vol. 27, no. 1, pp. 66-72, 2012.

[25] A. L. Martínez-Hernández, C. Velasco-Santos, M. de-Icaza, and V. M. Castaño, "Dynamical-mechanical and thermal analysis of polymeric composites reinforced with keratin biofibers from chicken feathers," Composites Part B: Engineering, vol. 38, no. 3, pp. 405-410, 2007.

[26] M. A. Meyers, P.-Y. Chen, A. Y.-M. Lin, and Y. Seki, "Biological materials: structure and mechanical properties," Progress in Materials Science, vol. 53, no. 1, pp. 1-206, 2008.

[27] A. L. Martínez-Hernández, C. Velasco-Santos, M. de Icaza, and V. M. Castaño, "Hierarchical microstructure in keratin biofibers," Microscopy and Microanalysis, vol. 9, no. 2, pp. 1282 1283, 2003.

[28] M. Zhan and R. P. Wool, "Mechanical properties of chicken feather fibers," Polymer Composites, vol. 32, no. 6, pp. 937-944, 2011.

[29] C. G. Flores-Hernández, A. Colín-Cruz, C. Velasco-Santos et al., "All green composites from fully renewable biopolymers: chitosan-starch reinforced with keratin from feathers," Polymers, vol. 6, no. 3, pp. 686-705, 2014.

[30] ASTM, "Standard test method for laboratory determination of water (moisture) content of soil and rock by mass," ASTM D2216-98, American Society for Testing and Materials, Philadelphia, Pa, USA, 1998.

[31] ASTM International, ASTM D7263-09, Standard Test Methods for Laboratory Determination of Density (Unit Weight) of Soil Specimens, American Society for Testing and Materials, West Conshohocken, Pa, USA, 2009.

[32] ASTM, "Standard test methods for specific gravity of soil solids by water pycnometer," ASTM D854-02, American Society for Testing and Materials, Philadelphia, Pa, USA, 2002.

[33] ASTM, "Standard practice for classification of soils for engineering purposes (Unified Soil Classification System)," ASTM D2487-00, American Society for Testing and Materials, West Conshohocken, Pa, USA, 2000.

[34] ASTM International, ASTM D4318-00, Standard Test Methods for Liquid Limit, Plastic Limit, and Plasticity Index of Soils, American Society for Testing and Materials, West Conshohocken, Pa, USA, 2000.

[35] ASTM, "Standard test method for shrinkage factors of soils by the mercury method," ASTM D427-04, American Society for Testing and Materials, West Conshohocken, Pa, USA, 2004.

[36] ASTM International, ASTM D4546-03, Standard Test Methods for One-Dimensional Swell or Settlement Potential of Cohesive Soils, American Society for Testing and Materials, West Conshohocken, Pa, USA, 2003.

[37] P. T. Hang and G. W. Brindley, "Methylene blue absorption by clay minerals. Determination of surface areas and cation exchange capacities (clay-organic studies XVIII)," Clays and Clay Minerals, vol. 18, no. 4, pp. 203-212, 1970.

[38] R. Greene-Kelly, "The specific surface areas of montmorillonites," Clay Minerals Bulletin, vol. 5, no. 31, pp. 392-400, 1964. 
[39] P. V. Sivapullaiah, B. G. Prasad, and M. M. Allam, "Methylene blue surface area method to correlate with specific soil properties," Geotechnical Testing Journal, vol. 31, no. 6, pp. 503-512, 2008.

[40] "Standard method of test for the qualitative detection of harmful clays of the smectite group in aggregates using methylene blue," AASHTO TP 57-06, American Association of State and Highway Transportation Officials, Washington, DC, USA, 2006.

[41] A. L. Martínez-Hernández, C. Velasco-Santos, M. D. Icaza, and V. M. Castaño, "Mechanical properties evaluation of new composites with protein biofibers reinforcing poly(methyl methacrylate)," Polymer, vol. 46, no. 19, pp. 8233-8238, 2005.

[42] S. Tripathy, K. S. Subba Rao, and D. G. Fredlund, "Water content-void ratio swell-shrink paths of compacted expansive soils," Canadian Geotechnical Journal, vol. 39, no. 4, pp. 938-959, 2002.

[43] F. Macht, K. Eusterhues, G. J. Pronk, and K. U. Totsche, "Specific surface area of clay minerals: comparison between atomic force microscopy measurements and bulk-gas $\left(\mathrm{N}_{2}\right)$ and -liquid (EGME) adsorption methods," Applied Clay Science, vol. 53, no. 1, pp. 20-26, 2011. 

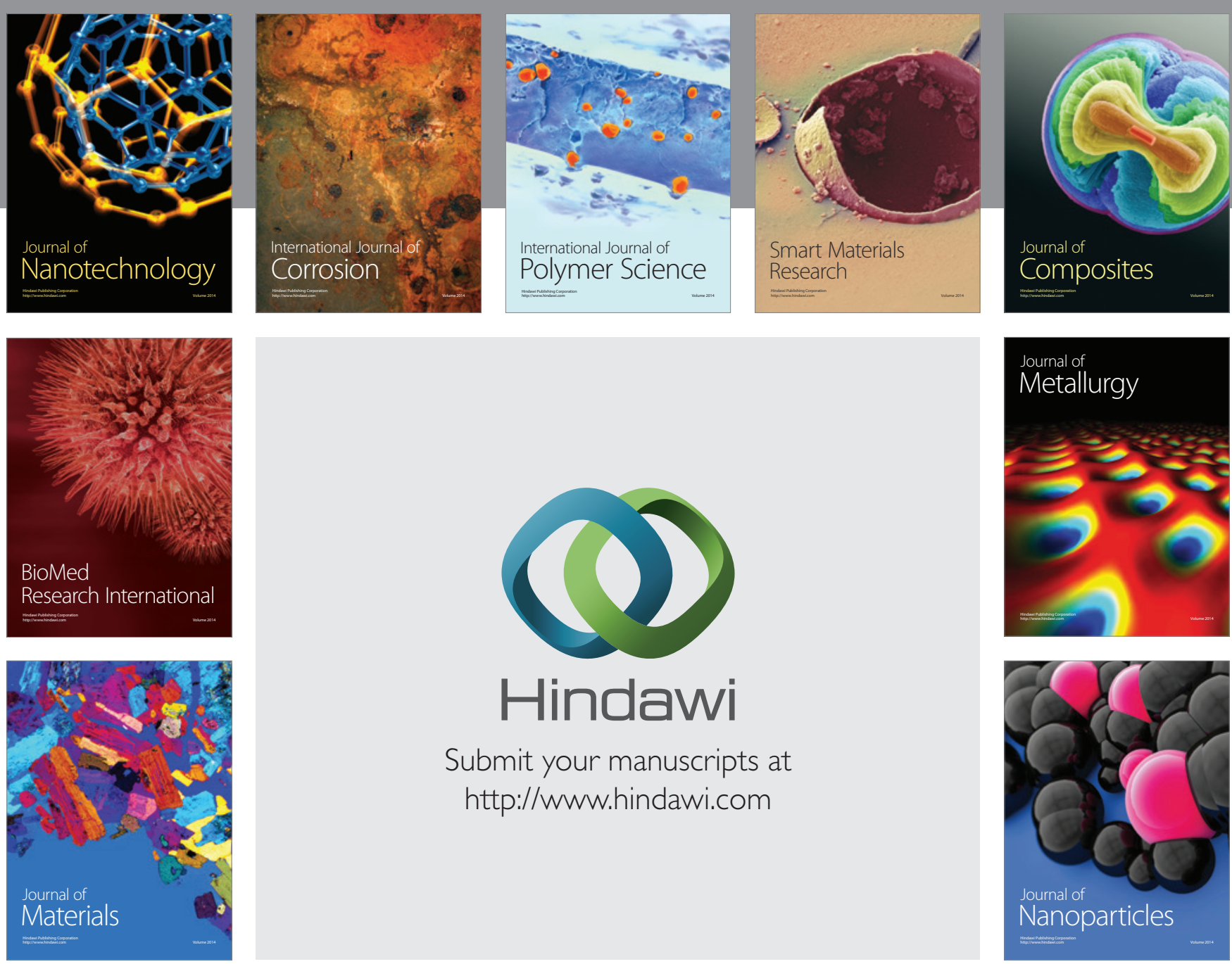

Submit your manuscripts at http://www.hindawi.com
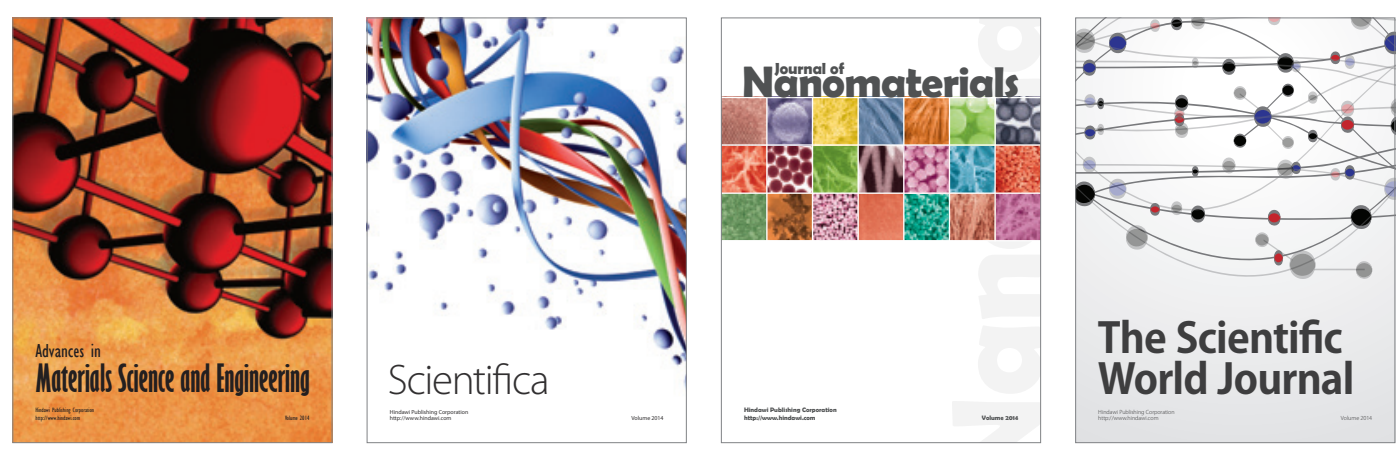

\section{The Scientific World Journal}
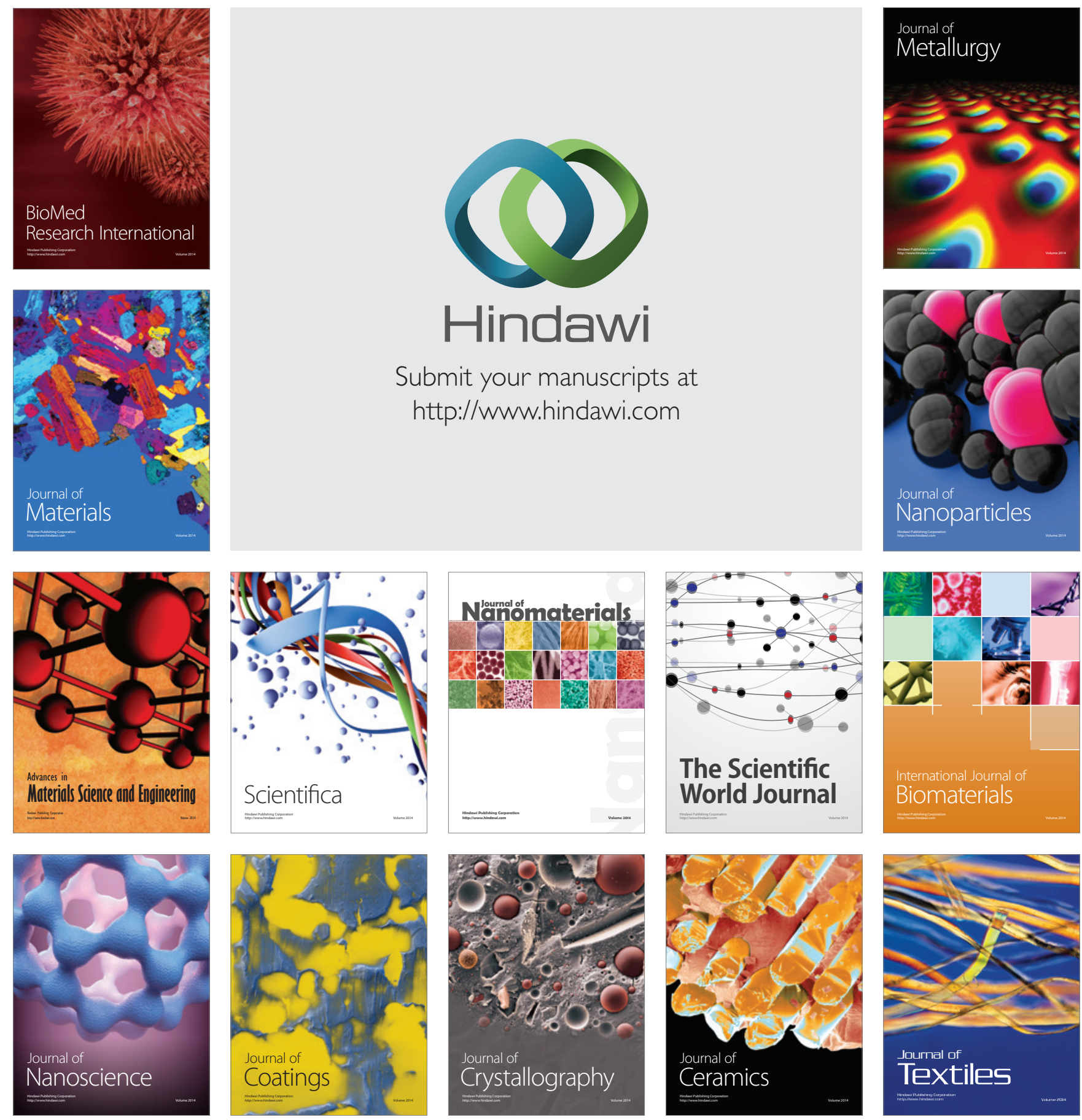